Özkiraz, A. \& Talu, N. / Sosyal Bilimler Araştırmaları Dergisi. 2, (2008): 108-126

\title{
Sendikaların Doğuşu; Türkiye ve Batı Avrupa Ülkeleri Karşılaştırması
}

\author{
Ahmet ÖZKİRAZ $\quad$ Nuray TALU ${ }^{\mathrm{b}}$
}

Özet

Sendikalar 18. yüzyılın sonlarına doğru İngiltere'de Sanayi Devrimi'nin yol açtığı olumsuz koşullar sebebiyle doğmuştur. Ancak Türkiye'de sendikaları doğuran koşullar ve sendikaların yapısı Batı Avrupa ülkelerinden farklılık göstermektedir.Çalışmanın amacı Batı Avrupa ülkeleri ile Türkiye'de sendikacılığın doğuşunu karşılaştırmaktır. Asıl amacı işçi hak ve çıkarlarını korumak olan sendikalar, ortaya çıkma süreçleri açısından Batı Avrupa ülkeleri ile Türkiye arasında benzerlikten çok farklılıklara sahiptir. Bu sonucun asıl saiki ise sanayileşme ve demokratikleşme sürecinin Batı'da Türkiye'den önce başlamış olmasıdır. Çalışma' da konu ile ilgili kitap, dergi ve makale gibi ikincil kaynaklar taranmış ve ulaşılan bilgiler yorumlanarak kullanılmıştır.

Anahtar Sözcükler: Sendika, Sendikaların doğuşu, Türkiye, Batı Avrupa.

\section{Emergence Of Trade-Unions: Comparison Between Turkey And Western- European Countries}

\begin{abstract}
Trade-unions emerged toward the end of the 18th century due to the negative conditions that industrial revolution had caused in England. However, the reasons which made trade-unions in Turkey come into being and the structure of these trade-unions are different from those in the West.

The aim of this study is to compare the emergence of trade-unions in Western-European countries with that in Turkey. Trade-unions whose original goal was to protect workers' rights and interests have, in terms of emerging process, dissimilarities between WesternEuropean countries and Turkey. The actual motive of this consequence is the fact that the process of democratization and industrialization in Europe started prior to in Turkey. For the study, such relevant resources as books, magazines, articles and etc. were scanned and the obtained data was interpretively used.
\end{abstract}

Key Words: Trade-union, Emergence of Trade-unions, Turkey, Western Europe.

\section{Giriş}

Sanayi Devrimi 18. yy.'ın ikinci yarısında İngiltere'de doğmuş ve oradan Batı Avrupa ülkelerine yayılmıştır. Sanayi Devrimi aslında makinenin ve onunla birlikte buhar ve büyük fabrika sanayinin doğuşu olayıdır ve ekonomik yaşamı ve onun kurumlarını derin bir biçimde değiştirmiş̧tir. Çağdaş sanayi tekniği 18. yy.'ın ikinci yarısından başlayarak şaşırtıcı bir hızla gelişmiş ve bu gelişme büyük ve derin toplumsal değişmelere yol açmıştır. Bu teknik ve

${ }^{a}$ Yrd.Doç.Dr, Gaziosmanpaşa Üniversitesi, İ̈BF, Kamu Yönetimi Bölümü, ahmeto@ gop.edu.tr

b Bilim Uzmanı, Nuray.TALU@ halkbank.com.tr 
toplumsal gelişme ve değişmeler, önceki dönemden farklı olarak, geniş bir işçi sınıfını ortaya çıkarmış, yeni yaşama ve çalışma koşulları yaratmış, kentlerin nüfusu hızla artmış, erkek, kadın ve çocuk işçileri zor, ağır ve insanı hızla yıpratan çalışma koşullarıyla karşı karşıya bırakmıştır.

Kapitalist sistem, küçük atölye sistemini yıkarak ve makineleşmeden önce imalathanelerde kalabalık işçileri toplayarak, vaktiyle loncalar içinde toplanmış öğeleri birbirinden ayırmış ve girişimcinin karşısına durmadan artan, yeni bir sinıf ortaya koymuştur.

Başlangıçta iktisadi liberalizmin etkisiyle çeşitli baskı ve yasaklamalarla sindirilmeye çalışılan sendikal hareket, kararlı mücadelelerden sonra, 19. yüzyılda hak olarak tanınmıştır. Sendika hakkı günümüzde gerek iç hukuk gerekse uluslararası hukuk metinlerinde temel insan hakkı olarak yer almaktadır. Başlangıçta işçilerin örgütlenme biçimi olan sendikalar, işçi sendikaları güçlenince işverenlerce de tercih edilmiş ve işçi sendikalarına tepki olarak işveren sendikaları kurulmuştur.

Çalışmanın amacı Batı Avrupa ülkeleri ile Türkiye'de sendikacılığın doğuşunu karşılaştırmaktır. Çalışma' da yöntem olarak konu ile ilgili kitap, dergi ve makale gibi ikincil kaynaklar taranmış ve ulaşılan bilgiler yorumlanarak kullanılmıştır.

\section{Batı Avrupa Ülkelerinde Sendikacılığın Doğuşu}

\section{1. İngiltere'de Sendikal Hareketin Ortaya Çıkışı}

Sendikal hareketin gelişmesi için gerekli iki koşuldan biri sanayileşme diğeri de demokrasinin varlığıdır. Bu iki koşulun gerçekleştiği ilk ülke İngiltere'dir (Tokol, 1984:221). Bu ülkede sanayileşmenin etkilerinin görülmeye başladığı 18. yüzyılın son çeyreğine kadar çalışma hayatı loncalar tarafından düzenlenmiştir (Yücel, 1980:221). Geleneksel üretim yapısı ve kapalı üretim tarzının yer aldığı loncalarda kalfaların ustalara kesin bağımlılığı söz konusudur (Ekin, 1989:6-7, Demircioğlu, 1987:61).

$\mathrm{Bu}$ bağımlılık başlangıçta büyük sorunlar oluşturmuş ancak ticari hayattaki hızlı gelişmeler ve ulaşım ve haberleşme sistemindeki ilerlemeler, makineleşme zamanla kalfa ve ustalar arasında önemli çatışmaların ortaya çıkmasına neden olmuştur. Değişen piyasa koşullarına ayak uydurmak isteyen ustaların çıraklık yasalarını çiğnemeleri ve ücret anlaşmalarını bozmaya başlamaları üzerine kalfalar "Dostluk Dernekleri” "Meslek Klüpleri” kurmaya başlamışlardır. Yerel nitelikte olan bu örgütler üyelerine, hastalık, işsizlik ve ölüm risklerine karşı sosyal yardım sağlamışlardır(Yücel, 1980:96-97).

Örgütlenme ihtiyaçlarının artması işçi hareketlerinin çoğalması üzerine 1789 ve 1800 yıllarında "Birleşme Yasaları" yürürlüğe girmiştir. Yasalar her türlü birleşmeyi yasaklamış, birleşmeye katılan kişileri üç aya kadar hapis ve ağır işte çalışma cezası verilmesini öngörmüştür. $\mathrm{Bu}$ dönemde örgütlenmenin suç olarak kabul edilmesinde devletin ekonomik ve sosyal hayatta her türlü 
Özkiraz, A. \& Talu, N. / Sosyal Bilimler Araştırmaları Dergisi. 2, (2008): 108-126

müdahalesini reddeden "liberal görüş"ün rolü bulunmaktadır. Birleşmeyi önleyen yasalara rağmen vasıflı işçiler arasında örgütlenmenin 1800'lü yılların başında hızla devam ettiği görülmektedir (Yücel, 1980:96-97).

İngiliz sendikacilık hareketi 1830'lu yıllarda Robert Owen'nn fikirlerinden etkilenerek yeni bir boyut kazanmıştır (Ekin, 1989:79). Üretim kooperatiflerine dayanan bir toplum düzeni ile işçilerin emeklerinin karşıllı̆ını alacağına inanan Owen bu düzenin sağlanmasında barışçı genel grevin etkili olabileceğini savunmuştur. Owen'a göre barış̧̧ı genel grevde en büyük desteği diğer sınıfların iyi niyetli insanları sağlayacaktır. Owen'ın fikirleri doğrultusunda 1834 yılında "Üretici Sınıfların Büyük Milli Manevi Birliği”" kurulmuştur (Işıklı, 1972:19-20).

Birlik kısa sürede çok sayıda işçiyi bünyesine almıştır. Ancak birliğe üye işçiler üzerinde devletin ve işverenlerin sürdürdüğü yoğun baskılar örgütün kısa sürede dağılmasına yol açmıştır. Owenizm hareketinin başarısızlığa uğraması üzerine "Chartizm Hareketi" işçiler arasında yaygınlık kazanmaya başlamışıtır. 1837-1848 yılları arasında işçileri etkileyen hareketin temel esasları bütün vatandaşlara oy hakkı verilmesi, seçim bölgeleri arasında eşitlik sağlanması, milletvekili adaylığı için ödenen vergilerin kaldırılması, seçimlerde oylamaların gizli olarak yapılması ve işgücünün on saat olarak belirlenmesi şeklinde sıralanabilir (Lefrance, Sülker, 1966:10).

Chartizm hareketi özellikle vasıfsız işçiler arasında yaygınlık kazanmasına karşılık vasıflı işçilerin denetiminde bulunan sendikalarla yeteri kadar dayanışma sağlayamadığı ve teorik bir yapıya sahip olamadığı için başarısızlığa uğramıştır (Işıklı, 1972:23-24).

Belli bir alanda ulusal düzeyde ilk sendika kurma girişimi 1851 y1lında makine ustaları tarafından gerçekleştirilmiş, "Birleşik Makine Ustaları Sendikası" kurulmuştur. Birleşik Makine Ustaları Sendikası merkezden denetlenen ilk ulusal sendikadır. Bu sendika sistemi ortadan kaldırmak yerine sistemle uyum içinde işçilerin kısa vadeli ekonomik çıkarlarını korumayı amaçlamıştır (Yücel, 1980:101-102). Sendika üyelerinden yüksek aidat almış, üyelerine çeşitli risklere yardım sağlamış, üyelerinin çıkarlarını vasıfsız işçilere karşı korumuştur (Jackson, 1992:24).

1860'larda Birleşik Makine İşçileri Sendikası modeli sendikalar yaygınlık kazanmaya başlamıştır. Duvarcılar, taş işçileri ve diğer meslek gruplarındaki işçiler büyük ulusal sendikalar oluşturmuşlardır. Öte yandan bugün varlığını sürdüren "İşçi Sendikaları Kongresi" de 118000 işçiyi temsil eden 34 sendika temsilcisinin bir araya gelmesi ile 1868 yllında kurulmuştur (Yücel, 1980:103-106).

$\mathrm{Bu}$ gelişmeler sonucunda sendikal hareketi gözden geçirmek amaciyla 1867 yılında bir Kraliyet Komisyonu görevlendirilmiş, komisyonun görüşleri doğrultusunda 1871 yılında yeni bir sendikalar yasası çıkarılmıştır. Yasa İngiliz sendikacılığında yeni bir dönem başlatmıştır. 1871 yılından sonra sendikaların 
faaliyetlerini düzenleyen çok sayıda yeni yasa uygulamaya konulmuştur (Ekin, 1989:78). Bu yasalar sendikalara tüzel kişilik kazanma hakkını, sendika fonlarının yasal olarak korunmasını, grev hakkını ve şiddete başvurmadan uyuşmazlığın genişletilmesini öngörmüştür (Talas, 1976:188).

İngiltere 1876 yılından 1888 y1lına kadar geçen dönem içinde büyük bir kriz içine girmiş, krizden vasıfsız işçilerin yanı sıra vasıflı işçiler de olumsuz etkilenmiştir. Bunun üzerine ülkede grev hareketleri yaygınlaşmış, ancak bunlar başarısızlıkla sonuçlanmıştır. Sendikaların büyük bölümü kapanmış, bir bölümü de üyelerini ve gelir kaynaklarını kaybetmişlerdir. Ülkede 1880'lerin sonlarına doğru Karl Marx'ın fikirleri bazı sendikacılar arasında benimsenmeye başlamış, ekonomik bunalımın etkisi ile taraftar toplamıştır. Marxist sendikacılar uzun dönemde ülkenin servetinden herkesin eşit pay almasını, işçilerin siyasi iktidarı ele geçirerek üretim araçlarının mülkiyetinin topluma mal edilmesini hedeflemişlerdir. Bu doğrultuda ilk grev hareketi kadın kibrit işçileri tarafından başlatılmış, bunu benzin işçileri ve Londra Liman işçileri grevi izlemiştir. Bu üç grevin de başarılı olması vasıfsız işçileri örgütleyen sendikaların kurulmasına imkan tanımıştır. Her meslekteki işçiyi örgütleyen yeni sendikalar meslek sendikalarına göre daha radikal bir tutum izlemişlerdir (Yücel, 1980:106-109, Jackson, 1992:25). Böylece İngiltere'de 1890'larda sendikal hareket yeni bir şekil almıştır. Bu değişmeler daha sonra İşçi Partisi'nin kurulmasına yardımcı olmuştur (Ekin, 1989:82).

\subsection{Almanya'da Sendikal Hareketin Ortaya Çıkışı}

Almanya'da sanayileşme hareketi oldukça geç tarihlerde başlamıştır. Ülkede 1850'lerden önce büyük sanayi kuruluşlarının sayısı sınırlıdır. Napolyon Savaşlarından sonra İngiliz sanayinin yeniden uluslararası piyasalara hakim olması Almanya'yı önemli ölçüde etkilemiştir. Alman hükümetleri 1825 yılından sonra sanayinin ilerlemesi için önlemler almaya başlamışlardır. Ancak Alman birliğinin sağlanamaması, loncaların varlıklarını sürdürmeleri, sermaye ve girişim yetersizliği sanayinin gelişmesini engellemiştir. 1840'lardan sonra başlayan sanayileşme büyük güçlüklerle karşılaşmış, özellikle loncalarda yer alanlar sanayileşme hareketine direnmişlerdir (Talas, 1976:231-232).

1848 Devrimi ülkede sendikal hareketin canlanmasına zemin hazırlamıştır. 31 işçi örgütü ile 3 işçi komitesi delegelerinin katıldı̆̆ bir işçi kongresi toplanmış, kongre sonunda ise ilk siyasi işçi örgütü olan "İşçi Kardeşliği”" oluşturulmuştur. Ancak 1848 Devriminin başarısızlığa uğraması üzerine 1854 yılında tüm sosyalist ve komünist görüşlü sendikalar kapatılmıştır (Tokol, 1989:1).

1860'l1 yıllar Almanya'da siyasi hareketliliğin görüldüğü yıllardır. Bu yıllarda gerek 1859 yılında kurulan "Alman Ulusal Birliği" gerekse liberal görüşü benimseyen "İş̧i Eğitim Birlikleri" işçilerin siyasi faaliyetlere katılmalarını sağlamak için yoğun çaba harcamışlardır. Aynı yıllarda Ferdinand 
Laselle'nin yayınladığı "Open Letter of Reply" adlı eser işçileri önemli ölçüde etkilemiştir. 1863 y1lında Laselle'nin görüşleri doğrultusunda "Alman İşçileri Genel Birliğii” kurulmuştur (Tokol,1989:1).

Laselle'nin amacı, işçilerin siyasi gücü ele geçirmeleri ve üretim kooperatiflerine dayalı bir toplum düzeni oluşturmalarıdır. Siyasi hareket ve mücadeleye inanan Laselle 1864 yllında öldüğünde ADAV (Alman İşçileri Genel Birliğ)' nin üye sayısı 4000 civarındadır.

Laselle'nin yanı sıra Karl Marx'ında Alman işçi hareketini etkilediği görülür. August Bebel ve Wilhelm Liebknect'nin liderliğinden sonra İşçi Eğitim Birlikleri Karl Marx'ın görüşleri doğrultusunda faaliyet göstermişlerdir. (Lefrance, Sülker, 1966:16-17) Öte yandan 1861 yllında Saksonya'da sendikal yasakların kaldırılmasından sonra birbiri ardına kurulmaya başlayan sendikaları etkilemek amaciyla gerek ADAV gerekse İşçi Eğitim Birlikleri'nin yoğun çaba harcadıkları görülmektedir.

Alman İmparatorluğu'nun 1871 yılında Bismark tarafından çıkarılan "Sosyalizm Yasası" sendikaların gelişmesini önemli ölçüde etkilemiştir. Bismark'ın sendikaları hedef almadıklarını belirtmesine karşın sendikalar yasadan büyük ölçüde etkilenmişlerdir. 17 federasyon, 39 yerel sendika, 3 merkezi sigorta fonu ve yerel sendika kapatılmış, tüm grevler şiddetle cezalandırılmıştır. Yasaya rağmen işçiler eğitim dernekleri, uzmanlık örgütleri adı altında bir araya gelmişlerdir. Hükümetin yoğun baskısına rağmen 1889 yılında Ruhr bölgesindeki madenciler greve gitmişler, bu grev hareketi Almanya'nın diğer bölgelerindeki madenciler tarafından desteklenmiştir. (Tokol, 2002:5).

Sosyalizm Yasası'nın 1890 yılında yürürlükten kaldırılmasından sonra Alman sendikal tarihinde yeni bir dönem başlamıştır. 1889 yılında ise sosyalist iş̧̧i hareketinin Paris'te yapılan kongresinde çalışma saatlerinin azaltılması amacıyla 1 Mayıs'ta çeşitli faaliyetler yapılması kararı alınmıştır. Bu karar üzerine Hamburg'da 1 Mayıs'ta gösteriler yapılmış, ancak gösterilere katılan işçiler işverenlerce işten çıkarılmışlardır. Bu durumu protesto etmek amacıyla işçiler aylarca direnmiş̧ler, işçilerin direnişi Almanya'nın diğer bölgelerinde yer alan işçilerce desteklenmiş̧ir.

1913 yılında Alman sendikaları gerek üye sayısı gerek mali yönden oldukça önemli bir güce ulaşmışlardır. Bu tarihte hür sendikalar 2.5 milyon, Hristiyan sendikalar 340 bin, liberal sendikalar (Hirsch-Dunker) ise yaklaşık 105 bin üyeye sahip bulunmaktadırlar. I. Dünya Savaşı'nın başlaması üzerine Alman sendikaları arasında ulusal dayanışma düşüncesi ağırlık kazanmaya başlamıştır. Sendikalar devletin sendikal faaliyetleri yasaklayacağı endişesi ile savaş sırasında devlete destek olma eğilimi içine girmişlerdir. Bu amaçla grevler sona erdirilmiş, sendikalar işçilerin gıda ihtiyaçlarının karşılanması, savaş malüllerine yardım edilmesi gibi yeni sorumluluklar yüklenmiştir. $\mathrm{Bu}$ durum sendikaların kamu organları tarafından kabul edilmesini sağlamıştır. 
1917 yılından sonra ise sendikaların desteği dışında kötüleşen koşullara bağlı olarak çeşitli grev hareketleri gündeme gelmiştir.

\subsection{Belçika'da Sendikal Hareketin Ortaya Çıkışı}

Belçika 1830 yılında bağımsızlığına kavuşmuş, 1831 Anayasası ile meşruti bir krallık haline gelmiştir. Sanayileşmenin yetersiz olması birleşmeyi ve işçi hareketlerini suç olarak kabul eden ceza yasası ülkede sendikal hareketin gelişimini uzun süre engellemiştir. 19. yüzyılın ilk yarısında vasıflı işçiler tarafından karşılıklı yardımlaşma, dostluk dernekleri oluşturulmuş ise de bunları sendikalar olarak kabul etmek güçtür (Tokol, 1993:21).

Ülkede ilk sendika 1857 yılında Gent'te tekstil işçileri tarafından kurulmuş, bu sendikayı 1859 yılında metal işçilerinin kurduğu sendika izlemiştir. 1860 yılında metal ve tekstil işçileri tarafından ilk bölgesel federasyon oluşturulmuştur. İzleyen y1llarda diğer bölge ve sektörlerde yeni sendikalar kurulmuş, ilk ulusal federasyon ise 1865 yllında kamu işçileri tarafından oluşturulmuştur (Tokol, 1993:21).

Ülkede kurulan ilk sendikalar ideolojik ve siyasi bakımdan bağımsızdır. Belçika' da işçiler arasında ideolojik bölünmeler ancak 1860'lardan sonra ortaya çıkmıştır. Hristiyan sendikal hareket 1886 yılından sonra gelişmeye başlamıştır. İlk Hristiyan sendikalar hastalık fonları, kültürel topluluklar, kooperatifler, bankalarca desteklenmiştir. Walloine ve Brüksel'de Hristiyan sendikaların temellerini Demokratik Federasyonlar, Flandre'de ise Lounvain'de kurulan loncalar oluşturmuş̧tur (Tokol, 1993:21).

Sosyalist tarafta ise 1885 y1lında kurulan "Belçika İşçi Partisi" sendikaların oluşturulması ve geliştirilmesinde etkili olmuştur. Parti sendikalar ve federasyonlar oluşturmak amacı ile 1898 yılında "Sendikalar Komitesi" kurmuştur. Belçika İş̧̧i Partisi'ne üye olmayan sendikaların da komitede yer alması ile komitenin adı daha sonra "Bağımsız Sendikalar ve Belçika İşçi Partisi Sendika Komitesi" olarak değiştirilmiştir. Komite temel olarak ulusal federasyonlar oluşturmayı amaçlamıştır(Tokol, 1993:22).

\subsection{Fransa'da Sendikal Hareketin Ortaya Çıkışı}

Fransa sendikal hareketin geç geliştiği ülkelerden biridir. Ülkenin ekonomik, sosyal ve siyasi yapısı sendikal hareketin oluşmasını uzun süre geciktirmiştir. 1789 Devrimi sırasında Fransa' da henüz sanayileşme hareketine rastlanmamaktadır. 1791 yılında çıkarılan "d'Allerde Yasası" ticaret ve sanayi özgürlüğü ile çalışma özgürlüğü sağlamasına rağmen siyasi istikrarsızlık ve savaşlar sanayileşmeyi engellemiştir. Bu konuda ilerlemeler Restorasyon (18141830) ve Temmuz Monarşisi (1830-1848) dönemlerinde sağlanmış ancak gerçek anlamda sanayileşme II. İmparatorluk (1852-1870) ve III. Cumhuriyet (1871-1940) dönemlerinde yani 19. yüzyılın ikinci yarısında gerçekleştirilmiştir (Gülmez, 1991:60,80). 
Siyasi yapı ise III. Cumhuriyetten sonra sendikaların gelişmesi için uygun bir nitelik kazanmıştır (Talas, 1976:244-245).

Fransa'da işçilerin ilk örgütlenme girişimlerini karşılıklı yardımlaşma toplulukları oluşturmaktadır. Bu topluluklar sadece vasıflı işçileri içermekte, üyelerine hastalık, yaşlılık, iş kazası, işsizlik gibi durumlarda yardımcı olmaktadır. Yardımlaşma toplulukları sahip olduğu fonksiyonlar nedeni ile önceleri devlet ve işverenlerce desteklenmiş, direnme topluluklarına dönüşmemeleri için sıkı bir denetim altına alınmışlardır. Ancak topluluklar zaman içinde aynı meslekteki kişilerin bir araya gelerek sorunlarını tartışıkları yerler haline gelmişler, özellikle 1830'lardan sonra bazı grev hareketlerine katılmışlar, grev hareketlerini yöneten direnme topluluklarına dönüşmüşlerdir.

Fransa'da işçilere yönelik gelişmeler 1848 Devrimi'nden sonra başlamıştır. 1848 Devrimi temelde bir işçi devrimi olarak bilinmektedir. Kentsoylular, Napolyoncular ve Cumhuriyetçilerin yardımı ile oluşan devrim toplumsal önderlerin iktidara gelmesini sağlamıştır (Talas, 1990:209). 24 Şubat'ta geçici bir hükümet kurulmuş, hükümet ilk olarak çalışma hakkı ve dernek kurma özgürlüğü tanımıştır. Geçici hükümet tarafından yapılan düzenlemeler izleyen yıllarda kurucu meclis tarafından tümüyle ortadan kaldırılmıştır (Talas, 1990: 119).

21 Mart 1884 yılında çıkarılan yasa ile sendikaların önceden izin almadan serbestçe kurulabilmelerine imkan tanınmıştır. Yasa sendikaların devlete karşı bağımsızlığını teminat altına almış, bireysel sendika özgürlüğünü kabul etmiş, sendika çokluğu ilkesini benimsemiştir. 27 Aralık 1892 tarihinde çıkarılan yasa ise toplu iş uyuşmazlıklarının çözümlenmesi ile ilgili düzenlemelere yer vermiştir. Yasa çalışma koşulları ile ilgili toplu iş uyuşmazlıklarının uzlaştırma komitesinde, bu komitede anlaşma sağlanamaması halinde hakem kurulunda çözümlenmesini öngörmüştür (Tokol, 1993:120).

Yasal düzenlemelerin ardından, ülkede sendika ve sendikalı işçi sayısı hızla artmıştır (Talas, 1976:246). Bu dönemde sendikal birliği sağlamak amacı ile yerel ve mesleki yapıda örgütler oluşturulmuştur. Yerel örgütler aynı yerde çalışan farklı meslekteki işçileri bir araya getiren "emek borsaları"dır. 1892 yılında ise anarko-sendikalist görüşü benimseyen "Emek Borsaları Federasyonu" oluşturulmuştur. Emek borsaları yardımlaşma, eğitim, propaganda hizmeti vermiş, "sendikal bağımsızlık" ilkesini benimsemiştir (Tokol, 1993:121).

\section{Türkiye'de Sendikacılığın Doğuşu}

\subsection{Cumhuriyet'in Kuruluşundan Çok Partili Döneme Kadar Sendikacılığın Gelişimi(1923-1946)}

Kurtuluş Savaşı zaferle sonuçlanmış ve bağımsızlık kazanılmıştır. Cumhuriyet'in ilanıyla ortaya ülkenin vatandaşlarının kimlik sorunu çıkmıştır. Çok uluslu bir imparatorluktan ulus devlete geçilmiş, fakat bunun toplumsal 
alanda karşılığı henüz oluşturulmamıştır. Ulus devletin ideolojik boyutunun oluşturulması zaman almıştır (Yükselbaba, 2001:84).

Yeni kurulan Cumhuriyet, sınıf çatışmasıyla uğraşmak istememiştir. Halk söylemi Kemalistlerin 1923'te kurdukları partinin adında kullanılmıştır: Halk Fırkası. Ayrıca her türlü muhalefetin yaratacağı fikir ayrılıklarından çekinmekteydiler ve bu farklılıklara tahammülleri yoktu. "İşçileri yeniden kazanmak, en azından öfkelerini yatıştırmak için şimdi acilen bir ideolojiye ihtiyaç vard. "Çare korporatizmde bulundu." (Ahmad,1995:139,145) Korporatizm ile sınıfsal ayrilıkların üzeri örtülerek toplum tek bir potada eritilmek istenmiştir.

Cumhuriyet sonrası işçiler lehine düzenlemeler yapılmamıştır. $\mathrm{Ne}$ sendika hakkı ne grev hakkı verildi. Bunun yerine işçilere korporatizm ilkelerine göre devletin gözetiminde uyumlu bir yaşam sürmeleri söyleniyordu (Ahmad,1995:143). Osmanlı'dan sanayi altyapısı devralınmamıştır. Sosyalist partiler Cumhuriyet öncesinde hiç kök salamamışlardır. Sınıf bilinci ise örgütlülüğün zayıflığından gelişememiş̧tir. Böyle bir ortamda ayrıca Kemalist ideoloji ile sarmalanan, "halkın devleti" diye tanımlanan bir devletle karşı karşıya olan işçilerin grev yapması, bazı taleplerde bulunması kolay değildir (Ahmad, 1998:147).

Bütün bu vasata rağmen 1923 yılı işçiler açısından birçok gelişmeye sahne olmuştur. Bunlardan birisi de 17 Şubat - 4 Mart 1923 tarihleri arasında İzmir'de toplanan İzmir İktisat Kongresi'dir.

$\mathrm{Bu}$ kongreye toplumun her kesiminden temsilciler katılmıştır. İşçiler de önemli ölçüde temsilcileriyle katılmıştır. Kongrede işçiler örgüt olarak Milli Türk Ticaret Birliği tarafından yönlendirilen İstanbul Umum Amele Birliği tarafından temsil edilmişlerdir. Kongrede işçiler ile ilişkili bir takım kararlar kabul edilmiştir (Genel-İş, 2000:10-11).

Ancak, İzmir İktisat Kongresi, hem yönetim, hem de farklı toplumsal katmanlar açısından daha sonra izlenecek iktisat politikalarına ışık tutmakla birlikte, Kongre'nin sonuçlarını abartmamak gerekir. Her şeyden önce, birbiriyle ne denli tutarlı oldukları, uygulanma olanakları, finansman yolları araştırılmadan ve öncelik dereceleri belli olmadan alınan bu kararlar bir program ya da plan olmayıp genel nitelikte dilekler görünümündedir (Sarc, 1983:349).

Asıl muhalefet ise, doğu illerinde 25 Şubat'ta patlayan ayaklanma olmuştur. Bir kürt isyanı olarak bilinen ayaklanmada ulusçu yönler olsa da isyana büyük ölçüde dini öğeler hakim olmuştur. Mustafa Kemal krizlere karşı çözüm üreten biri olarak, önce Başbakanlıktan Fethi Bey'i alıp yerine İsmet Paşa'yı getirmiş̧ir. Bundan sonra 4 Mart 1925'te acilen Takrir-i Sükun Kanunu çıkarılmıştır. 4 Mart 1929'da kaldırılan bu kanun Meclis'e olağanüstü yetkiler vermektedir (Zürcher,2000:245-246). Terakkiperverci muhalefetin kanunun Anayasa'nın 70'inci maddesine aykırı olduğunu öne sürmesine karşın kabul 
edilen Takrir-i Sükun Kanunu, işçi örgüt ve eylemleri için yasaklayıcı bir çerçeve oluşturmuştur.

Hükümetin işçilerin örgütlenmelerini de engelleyen bu tutumu o gün iktidar partisi olan CHP'nin işçi kitlelerinin bilinçlenmelerini, kendi hak ve çıkarlarını birleşerek aramalarını istemediğini göstermekteydi. Bütün partileri kapatarak güdümlü bir yönetime giden CHP, işçi kuruluşlarının kendi isteklerine ve görüşlerine göre yönetilmesi amacıyla giderek daha sıkı tedbirlere başvurmaktaydı.

Takrir-i Sükun sonrasında 1930'lardaki ekonomi siyaseti yine aynı temelden yürütülmekteydi; "toplumsal barış"1 korumak. Bunun için ceza yasasındaki 141. ve 142. madde "komünist propaganda"nın çok geniş yorumlanmasında kullanılmıştır. Her türlü eleştiri bu maddenin içerisine sokulmuş ve düzinelerce insan bu nedenle tutuklanmıştır (Ahmad, 1995:143).

Sınıflar arası uçurumun arttı̆ğ böyle bir ortamda CHP'ye karşı tepkiler de yoğunlaşmıştır." Tek parti sisteminde Cumhuriyet Halk Partisi'nin devlet aygıtıyla sıkıca özdeşleşmiş olmasından dolayı, bu hoşnutsuzluk devlete olduğu kadar partiye de yöneliktir." Bütün bu gerilimlerin farkında olan iktidar siyasal anlamda yeni açılımlar oluşturup, liberalleşmeye yönelmeye karar vermiştir. Bu kararda uluslararası konjonktürün de payı bulunmaktadır (Zürcher, 2000:302).

\subsubsection{CHP'nin İşçi Sınıfı Hareketine Yaklaşımı}

CHP 1931'de Türkiye'nin sınıflı bir toplum olmadığını programına dahi geçirmiştir. "Cumhuriyet Halk Fırkası her bakımdan bir iktidar tekeli kurmuş ve 1931'deki parti kongresinde Türkiye'nin siyasal sistemi tek parti sistemi olarak ilan edilmiştir ( Zürcher,2000:257). Program üzerinde tartışılırken parti sekreteri şöyle diyordu: "Memlekette bir sınıf şuuru uyandıracak tahrikat hissediliyor. Biz bu zeminde uyanık olmak lüzumuna kaniiz.”(Eriş̧̧i, 1951:21 ) Ayrıca yapılan konuşmalarda partinin tüm halkın çıkarlarını koruyan bir kuruluş olduğu ifade edilmiştir. CHP'nin dikkate aldığı sınıflar arasında işçiler ve köylüler olmamıştır. Sanayinin fazla gelişmediği bir ülkede işçileri ve çıkarlarını ifade etmek gereğini duymamışlardır (Cumhuriyet, 29 Ocak 1931'den aktaran Ahmad, 1998:146). "CHP hem burjuva yönüyle, hem de ulusal burjuva oluşturma amacı dolayısıyla, karmaşık bir partiydi"(Eroğul, 1994:44-49).

CHP sınıf bilincini uyandırmasına meydan verecek örgütlerin kurulmasını ve yaşamasını istememiştir. Bu nedenle işçilerin örgütlenmelerine izin verilmezken, o sıralarda hazırlanan Esnaf Cemiyetleri Talimatnamesi ile esnaf arasında meslek esasına dayanan cemiyet kurulmasına izin verilmekteydi. Sendika biçiminde olmamak üzere kurulan dernekler, mesleğin teknik bakımından gelişmesi, meslek anlaşmalarının çözümü ve meslektaşlar arasında dayanışma ve yardımlaşma sağlanması gibi işlerle uğraşmış, sınıfsal çıkarlar ardında koşmamışlardır. Esnafa dernek kurma izni veren hükümet sınıf ilkesine 
dayanan sendika kurmasına, işçilerin sosyal ve ekonomik çıkarlarını elde etmek için sosyal alanda mücadelelere girişmelerine izin vermemiştir. Böyle güdümlü bir ortamda işverenlerin istedikleri gibi davranmaları, ücretleri keyfi ayarlamaları, işçileri yer altı mücadelelerine doğru kaydırmıştır (Sülker, 1955:29).

İşçi hareketleri baskı yoluyla durdurulamayınca, 1931 seçimlerinde CHP yöneticilerinin izniyle, bazı işçi liderleri milletvekili adayı gösterilmişlerdir. Hükümetin yardımlarıyla işçi örgütlerinin çoğu yardım sandıkları şekline dönüştürülmüştür. Böylece dolaylı yollardan egemen çevreler, işçi kitleleri üzerinde ekonomik bir baskı düzeni kurmuşlardır.

1935 'lere gelindiğinde devletçilik ilkesi hem en tepe noktasında hem de en tartışmalı döneminde bulunmaktaydı. Çünkü "ne parti ne de hükümet, devletin ekonomiye müdahalesinin sinırlarını, özel sektörü ve bu sektörün CHP içindeki destekçilerini tatmin edecek şekilde tanımlayabilmiştir”. Bu belirsizlik toprak ağalarını, burjuvaziyi rahatsız etmekteydi. Toprak ağaları toprak reformu yapılamayacağı konusunda garanti verilerek sakinleştirilmekteydi. Yükselen kapitalist sınıf devletçiliğin kendilerini nasıl etkileyeceğini bilemiyordu. Parti Genel Sekreterliğine Recep (Peker)'in getirilmesi (1931) kapitalistleri daha da endişelendirdi. Recep (Peker), totaliter bir eğilim sergiliyordu ve bu CHP'nin devlet üzerindeki ağırlığını artırmıştır. "Nihayet 1935 'te, Almanya' daki örneği izleyen CHP parti ile devletin birleşmesini öngören bir tasarıyı kabul etmiştir; genel sekreter İçişleri Bakanlığı görevine getirilirken, partinin il başkanları vilayetlerine vali olarak atanmışlardır." (Ahmad, 1995:127,129).

Bütün bu süreç, bürokrasinin reformlarla sökülemeyecek bir şekilde kök salmasını sağlamıştır. Dünya'da kriz sürecine girilmiştir; Almanya gittikçe güçlenmektedir. Almanya'nın bu ş̧ekilde güçlenmesi Türkiye'yi -geleneksel olarak Almanya yakınlığı Osmanlı'nın özellikle son aşamasında başlamıştı- bu devletle yakınlaşmaya götürdü; bundan siyaset ve ideoloji de etkilenmiştir (Ahmad, 1995:94).

Dönemin kısa ömürlü iki muhalefet partisinden yalnızca Terakkiperver Cumhuriyet Fırkası'nın programında işçi sorununa genel bir anlatımla yer verilmiştir. 35. maddeye göre, "sermaye ile say ü amel münasebatı tanzim ve sermayedar ile imal ve mesai erbabının hukuk ve menafi aynı suretle müdafaa edilecektir." 36. madde ise "amelenin temettüe iştirak ettirilmesine taraftarız. Fakat bunu kanun kuvvetiyle değil, ikna suretiyle temin etmeye çalışacağız" denilmektedir (Tunaya, 1952:619). Görüldüğü gibi devletin görevlilerinin "hadd-i asgari"ye indirilmesinden yana olan ve liberal ekonomi görüşünü benimseyen fırka, işveren ile çalışanın hak ve çıkarlarını "aynı suretle", aralarında herhangi bir ayrım gözetmeksizin ve eşit taraflar olarak savunmayı amaçlamaktadır. Öte yandan programda işçinin kara katılmasından yana olduğunun açıklanması oldukça ilginçtir. 
Özkiraz, A. \& Talu, N. / Sosyal Bilimler Araştırmaları Dergisi. 2, (2008): 108-126

Serbest Cumhuriyet Fırkası'nın hiçbir hazırlık yapılmadan yayımlanan 11 maddelik çok kısa programında ise, işçi-işveren ilişkilerine hiç değinilmemiştir (Tunaya, 1952:633-634). Buna karşın, hoşnutsuz halk kitlelerinin varlığını ortaya çıkaran bu muhalefet deneyi, "Cumhuriyet Halk Fırkası'nı çalışanların lehine atılımlar yapmaya, daha doğrusu yapar görünmeye itecektir (Gülmez, 1983:186).

\subsubsection{Kanunlarda Yapılan Düzenlemeler ve 1936 İş Kanunu}

8 Haziran 1936'da 3008 sayılı İş Kanunu Meclis'te kabul edilmiş 1937'de yürürlüğe girmiştir (Yavuz, 1998:165). Kanun çıkartılıncaya kadar birçok kanun tasarısı meclise gelip gitmiştir. Bu konuda 1923'de İzmir İktisat Kongresi'nde karar alınmıştır. 5. İcra Vekilleri Heyeti Reisi Ali Fethi Okyar'ın hükümet programında da böyle bir yasa yer almıştır. Cumhuriyet'in ilanından sonra Ali Fethi Okyar hükümetinin (22.11.1924-03.03.1925) ve 6. İnönü hükümetinin (04.05.1931-01.03.1935) programlarına girmiştir. Fakat İş Kanununun çıkması ancak 7. İnönü hükümeti döneminde, 1936'da çıartılmış, 1937 yılında yürürlüğe girmiştir (Iş̧1k, 1995:89, Yavuz, 1998:164). Bu kanun o güne kadar gündeme gelen tasarılardan daha antidemokratik ve bürokratiktir (Erişçi, 1951:23). 1923'te savaştan çıkılmış olmasına rağmen işçilere daha fazla hak verilmiş̧ir. Bunun nedeni siyasal iktidarın kendini sağlamlaştırma sürecinde olmasıdır. 1936'da ise siyasi iktidarın kendini sağlamlaştırma sürecini tamamladığını ve artık muhalif güçlerin sindirilmesi zamanının geldiği dönemdir.

Sürekli gündeme gelip giden bu tasarılardan 1924 tarihli olanında grev hakkı tanınmıştır. Bu tasarı 1929 tarihinde hükümet tarafından geri çekilmiştir. 1928 ve 1932 tarihli tasarılarda grev ve sendika hakkı gündeme getirilmemiştir. 1936 tarihli yasa gündeme geldiğinde Sanayi Birliği tasarıya karşı çıkmıştır. Bu tasarının işverenlere yüklediklerinin çok fazla olduğunu, bunun ise hem ekonomiye hem de işçilere zarar vereceği söylenmiştir. Eğer bu tasarı yasalaşırsa sermaye yatırım yapmayarak rantiyeliğe yönelecek ve işçiler işsiz kalacak şeklindeki söylemler aslında işveren kesiminin tehditleridir. İşverenlerin talepleri şu şekilde sıralanabilir: Bazı durumlarda ihbara gerek duyulmaksızın işten çıkarabilme, lokavt hakkı, terk-i hizmet yasağının getirilmesi, çalışma süresinin 50 saat olması gibi... Hükümet İş Kanunu için ABD'li uzmanlardan da görüş almıştır. $\mathrm{Bu}$ uzmanlar işkoluna göre sınıflandırma yapılmasını, sayım yapılmasını, asgari ücretin saptanmasını, ayni ücretin kaldırılmasını, vasıflı eleman yetiştirilmesi için önlemler alınmasını önermişlerdir. Öneriler arasında grev ve sendikalaşma hakkının verilmesi bulunmaktadır(Iş̧ı, 1995:90-95).

CHP 4. Kurultayı'nın sonucunda programına, "İş anlaşmazlıklarının uzlaşma yoluyla, olmazsa uzlaştırma araçlarının yargıçlığı ile giderilmesi ve grev ve lokavtın yasaklanmasını sağlayacak bir iş kanunu" çıkartılmasını 
Özkiraz, A. \& Talu, N. / Sosyal Bilimler Araştırmaları Dergisi. 2, (2008): 108-126

koymuştur (Işık, 1995:90-95). "Kanunun hazırlanmasında İtalya iş mevzuatından yararlanılmıştır."(Karpat, 1967,:100'den aktaran Timur 1997:146, Zürcher, 2000:291) Kanun hazırlanırken işçilere söz hakk1 verilmemiştir, fakat Meclis'te işçilere büyük övgüler arasında kabul edilmiştir (Timur, 1997:157). İş Kanunu tartışmalarında İktisat Vekili Celal Bayar tasarının "güzelleşmişs" ve "iyileşmiş" olduğunu ifade etmiştir. 1936 Kanunu çıkartılırken, Muvakkat Encümen Mazbatasında vurgulandığı gibi, "memlekette başlamış olan endüstri hayatını milli bir varlık halinde görmenin ve bu intizam ve ahengi bozabilecek herhangi bir ihtilafı, Devletin kuracağı telif vasıtalarının hakemliği ile halletmenin iktisadi bünyemize en uygun bir yol" olduğu görüşü oybirliğiyle kabul edilmiştir (TBMM Zabıt Ceridesi, 1936:49'dan aktaran Gülmez, 1995:173).

Sendika kurmak kanunla yasaklanmıştır. Sendikaların yasak olduğu bir ortamda bunun yerine uzlaşma sistemi yürürlüğe konmuştur. $\mathrm{Bu}$ sistemin unsurları işçi temsilcileri, devlet ve işverenlerdir. Ayrıca uzlaşma olmasa bile kanun 72. madde ile grevlere katı yasaklar getirmiştir. 73. ve 75. maddeler grevlere karşı sert hükümler içermektedir. 74. maddeye göre lokavtlar da yasaktır. Bu kanunun grev tanımı da oldukça katıdır. 73. maddeye göre üç işçinin yan yana gelmesi ve üretimi kısmen veya tamamen aksatması hali grev sayılmaktadır. 127. ve 128. maddeler işverenin iş sözleşmesini feshetme hakkını tanımlamaktadır.

1936 yasasının birincil özelliği, ulus ve halkla kaynaşma temeline dayanan tek parti ideolojisiyle devletçi ekonomi politikası anlayışını zorunlu öğeleriyle birlikte çalışma ilişkileri alanına yansıtması, dolayısıyla da devletin çalışma yaşamının tüm sorun ve alanlarına biricik ve düzenleyici aktör niteliğiyle kapsamlı karışmasının simgesi; kısacası, "rejimin iş yasası" olmasıdır (Gülmez, 1995:162).

İş Kanunu sınıfsallaşmayı engelleyen bir çerçevede kurulmuştur (Timur, 1997:155). İşçilerin dayanışma ve mücadele bilincini geliştirecek sendikal örgütlenmeye izin verilmemiş, grev ise anlamsız kalacak şekilde sınırlandırılmıştır.

Cumhuriyet'in ilanından sonra 1924 Anayasası'nın getirdiği toplanma ve dernek kurma hakkı 1925'te yürürlüğe giren Takrir-i Sükun Kanunu ile kaldırıldı. Bu kanun, her türlü mesleki ve siyasi örgütlenmenin yanı sıra grevleri de yasaklamıştı. Öte yandan Ceza Kanunu'nda 1933'te yapılan değişikliklerle grev ve lokavt yasakları cezai hükümlerle kuvvetlendirilmiştir (Ekin, 1987:231). Kanunlardaki düzenlemelerden birisi de 1936 yılında yapılan düzenlemedir. 141 ve 142. maddeler İtalyan Ceza Kanunu örnek alınarak daha da ağırlaştırıldı. 
Özkiraz, A. \& Talu, N. / Sosyal Bilimler Araştırmaları Dergisi. 2, (2008): 108-126

\section{2. Çok Partili Dönemden 1960'a kadar Sendikacılığın Gelişimi(1946-1960)}

\subsubsection{Cemiyetler Kanunu Sonrasında İşçi Örgütleri}

1938 yllında kabul edilen Cemiyetler Kanunu'nun maddesinin (h) fikrası, "Aile, cemaat, ırk, cins ve sinıf esasına veya adına dayanan cemiyetler kurulamaz. "hükmü ile sendika kurma hak ve hürriyetini tamamen ortadan kaldırmıştır. 4919 sayılı Cemiyetler Kanunu'nun 1946 yılında yürürlüğe girmesinden sonra, bu durum son bulmuştur. Yeni Cemiyetler Kanunu, sendikaları veya sınıf esasına dayanan dernekleri, kurulması yasak dernekler arasında saymamıştır. Ayrıca, eski kanunda sendika kurmayı yasaklar mahiyette yer alan 9. madde, sendika kurma hürriyetini sağlayacak yönde değişikliğe uğramıştır. Oysa 1946 Cemiyetler Kanunu, getirdiği yeni hükümlerle, işçilerin dernekler halinde teşkilatlanmalarına belli bir ölçüde imkan hazırlamıştır. "Yeni dernekler kanununa göre sınıf esası üzerine dernekler kurulmasına izin verilmesinden sonra birçok büyük şehirlerimizde çeşitli sendikalar kurulmuş ve çalışmaya başlamıştır" (Talas, 1963:36-37). Bu suretle sendikaların sayısı, Sendikalar Kanunu'nun kabul edildiği tarihlerde 100'e yaklaşmıştır. 10 Haziran 1946'da bu konuyla ilgili olarak Cemiyetler Kanunu'nda yapılan değişikliğe göre, cemiyetlerin ve bu arada işçi sendikalarının faaliyetlerini sınırlayan bazı maddeler kaldırılmıştır. Ancak CHP, işçi emekçilerin sınıf temeli üzerine örgüt kurulmasına konulan yasağı kaldırmamıştır.

Sendika kurma yasağının kaldırılması ilk bakışta büyük bir sevinç uyandırmış ise de yasanın sendika özgürlüğünü kısıtlayıcı birçok hükümleri beraberinde getirmesi bu sevinci gölgelemiştir. Sendikaların politika ile, siyasal propaganda ile ve siyasal yayınlarla uğraşmama hükmü işçi sendikalarının çalışma alanını çok daraltmaktaydı. Ayrı bir madde ile sendikaların ulusal çıkarlara aykırı hareket edemeyeceklerinin belirtilmesi; grev yasağının hüküm süreceği bir dönem içinde işçi sendikalarını kıskıvrak bağlayacak nitelikte olmuştur.

CHP sendikaların teşkilatlanmasında yardımcı ve önayak olurken kendisine yakınlığı olan, hatta parti mensubu olan işçilerin yönetici kadroları işgal etmeleri amacını gütmüş ve bu yoldan belli bir ölçüde sendikaların faaliyetlerini kontrol edebilme imkanını elde etmiştir. Bu maksatla Sendikalar Kanunu yürürlüğe girdikten sonra, CHP'ye bağlı bir "işçi bürosu"nun kurulduğu görülmektedir (Talas, Dilik, Işıklı, 1963:41).

CHP iktidarının sendikalara mali yardımları da olmuştur. Sendikalar, kuruluşlarının hemen ilk yıllarından itibaren aidatın iyi toplanmaması ve işçi kitlesinin bilgisizliği dolayısıyla hükümetten para yardımı talep etmek durumunda kalmışlardır. Sendika bağımsızlığı ile bağdaşmasına imkan olmayan bu yoldaki tatbikata İş Kanunu'nun 30. maddesi başlıca imkanı sağlamıştır. Bu 
maddede mevcut hüküm gereğince, işverenler cezalı işçilerin ücretlerinden yaptıkları kesintiyi her yıl Çalışma Bakanlığı'nda biriken bu paraların bir kısmı sendikalara yardım olarak kullanıldığından, özellikle sendikacılığın ilk yıllarında bazı merkez ve üst kademe kuruluşları için zaman zaman yararlandıkları önemli bir kaynak teşkil etmiştir.

DP çeşitli sınıfların çıkarlarının genellikle kamu yararı çerçevesinde uzlaştırılmasına inanmaktaydı. Sosyal, ekonomik ve mesleki amaçlarla dernek ve sendikalar kurabileceğini, sendikalara ise her türlü politik amaçlar dışında kalmak üzere grev hakkının tanınması gerekliliğini savunmaktaydı. Öteden beri grev hakkını isteyen işçiler bu vaat yüzünden DP'yi desteklemeye başlamışlardır. DP bunun yanında her türlü sosyal ve ekonomik tedbirlerin alınarak işçilerin rahat bir yaşama düzeyine kavuşturulacağını ileri sürmüştür. Dönemin diğer partilerinden Sosyal Adalet Partisi, sosyalizm, adalet ve devletçilik prensiplerinin birleştirilmesine çalışacağını söylüyor, İngiliz hayranı Çiftçi ve Köylü Partisi düşüncelerinin iktidar partisiyle aynı olduğunu bildiriyor, Sosyal Demokrat Parti ise, ülkede vatandaşların gereksinimlerine göre sendika kurulmasını gerekli bulmaktaydı. Türk Sosyalist Partisi ise her türlü adaletsizliği ortadan kaldırarak emek ve geleneklerini hak ettikleri biçimde değerlendirmek amacını taşımaktaydı. Türkiye Sosyalist Emekçi ve Büyük Köylü Partisi ise geniş halk yığınlarının giderek yoksullaşması sonucunu doğuran işgücünün sömürülmesini ortadan kaldırmayı istemiş, geniş halk yığınlarını siyasal özgürlükleri uğruna mücadele yapmaya çağırmıştır (Eroğul, 1970:14).

Ancak, bunlardan hiçbiri en bilinçli ve en güçlü muhalefet öğesini oluşturan büyük toprak sahiplerinin temsilcisi DP ile rekabet edecek durumda değildi. DP diğer bazı muhalefet öğelerinin yanı sıra işçi sınıfının geniş̧ desteğinden yararlanmayı ve işçilerin baş koruyucusu olarak görünmeyi başarabilmiştir (Çeçen, 1973:20).

"CHP ile DP arasında, işçi sendikalarını ve sendika birliklerini kendi yanlarına çekebilmek için çetin bir mücadele başlar. Her iki parti de bu amaçla, sendika örgütlerine ve yönetim kurullarına kendi ajanlarını yerleştirirler, bazı sendika liderlerini para ile veya yüksek mevkiler vaat ederek satın almışlardır. Ancak her iki parti de, sendika hareketini sinıf temelleri üzerine oturtmak isteyen kadrolara karşı, hükümetin ve yerel makamların desteğiyle şiddetli baskı uygulayıp, bu gibi girişimleri önlemişlerdir.

\subsubsection{Demokrat Parti'nin İktidara Gelişi ve İşçi Sınıfına Karşı Uygulamalar \\ Üzerine gölge düşen bir seçimle iktidarını sürdüren CHP, muhalefet baskısı altında kendi programında değişiklikler yaparak ve parti ile devleti liberalleştirerek tepki vermiştir. Kararlı bir laisist olarak bilinen İnönü ve CHP artık okullara din dersi konulması kararı alma noktasına gelmiştir.}


Özkiraz, A. \& Talu, N. / Sosyal Bilimler Araştırmaları Dergisi. 2, (2008): 108-126

Liberalleştirme siyaseti 1950 seçimlerine kadar hız kazanarak sürmüştür (Ahmad, 1995:154).

Dünya'da soğuk savaşın başlaması Yunanistan'da iç savaşın patlaması her iki partiyi dış dünyanın siyasal açıdan "istikrarlı Türkiye" isteğine uygun davranma yönelimine götürmüştür (Ahmad, 1995:154). CHP bir taraftan burjuvaziyi sürekli olarak tatmin etmeye çalışırken bir taraftan da İslami uygulamadaki kısıtlamaların kaldırılmasını isteyen kesimleri yatıştırmaya çalışmış, tavizler vermiştir. Fakat CHP ile özdeşleşmiş bulunan "jandarmalı, tahsildarlı ceberrut devlet" imgesi birçok girişime rağmen unutturulamamıştır (Ahmad, 1995:155).

14 Mayıs 1950'de yapılan milletvekili genel seçiminde Cumhuriyet Halk Partisi yenilmiş ve iktidar Demokrat Parti'nin eline geçmiştir. "Beyaz İhtilal" diye anılan bu seçimlerde DP oyların \%53,3'ünü, CHP oyların \%39,9'unu ve Millet Partisi (MP) \%4,8'ini almıştır (Savran, 1995:90-91).

DP iktidarının ilk yıllarında işçilere grev hakkını vermek üzere bir kanun tasarısının hazırlandığı kamuoyuna açıklanmıştır. Ancak çok geniş kısıtlamalar taşıyan bu tasarı Meclis'e sunulmadan rafa kaldırılmıştır. DP'nin 15 Ekim 1951 'de onaylanan programında ise bu haktan ve buna ilişkin olarak toplu sözleşme hakkından söz edilemez. 1952'den sonra DP iktidarının sözcüleri bu hakları vermenin kolay olmayacağını, derin incelemelere ihtiyaç gösterdiğini açılamaya başlamışlardır ve bu konuda öncelikle sendikalardan gelen taleplere karşı gittikçe ağırlaşan baskılar uygulanmıştır (Iş̧1klı, 1979:360).

Nitekim Başbakan Menderes'e kabinede, partinin Türk işçilerine grev vaadinde bulunduğu hatırlatıldığında sabırsızlıkla şu karşılığı verdi: "Bırakın bu saçmalığı. Türkiye' de grev olur mu? Bırakın biraz ekonomik gelişme olsun, bu konuyu o zaman düşünürüz" (Ahmad, 1995:158).

DP iktidarı, bir yandan sendikaların en ilkel fonksiyonlarını bile "siyaset" olarak nitelendirerek yasaklarken diğer yandan sendikaları, kendi çizgisinde politize etmek için büyük çaba sarf etmiştir. Aslında bu dönemde ve genellikle siyaset sayıldığı için siyasal iktidarın karşı çıktığı hareketlerin ortak yanı, siyasal iktidar tarafından karşı̂t görülmektedir. Sendikalarda siyasal iktidarın görüşlerine ve tercihlerine uygun bir doğrultuda beliren tutum ve eylemler, en koyu bir siyasal nitelik taşısalar bile herhangi bir yasakla karşılaşmadıkları gibi çoğu zaman siyasal iktidarın destek ve zorlamaları sonucunda belirmişlerdir (Işıklı, 1979:363).

\subsection{Amerikan Tipi Sendikacılık ve Türk-İş'in Kurulması}

1946 yılında sendikaların kurulmasında yaşanan patlama ve bu sendikaların ağırlıklı olarak sosyalist hareketle organik bağının olması CHP'yi de bu konuda adım atmaya zorlamıştır. Türkiye'ye Cumhuriyet döneminde ne getirilmesi gerekiyorsa kendisi getirmeye alışmış olan CHP bu kez de işçi 
Özkiraz, A. \& Talu, N. / Sosyal Bilimler Araştırmaları Dergisi. 2, (2008): 108-126

sendikalarının kurulmasına önayak olmuştur. Fakat CHP ve sonraki gelen hükümet DP ancak Amerikan tipi sendikacılığı kabul edebilmişlerdir.

Amerikan tipi sendikacılık Toker Dereli tarafından şu şekilde tanımlanmıştır: "Başlıca işlevini üyelerinin ekonomik ve mesleki çıkarlarını gözetmek ve geliştirmek olarak gören, ABD sendikacılığını belirleyen sendikacılık anlayışı." Amerikan tipi sendikacılığının temel özelliği, kapitalist sistemde bütünsel değişimler öngörmemesi, varolan işçi ve kapitalist sınıfların yalnızca ekonomik tartışmaları, sendikaların siyasetle ilgilenmemesi ilkeleri üzerine kurulmuştur (Dereli, 1996:41-44).

Türkiye'de sendikacılıkta ABD etkisi 1951 yılında başlamıştır. ABD gelişmekte olan işçi hareketlerinin kontrol altına alınması konusunda son derece duyarlı ve deneyimlidir. Bu etkiyi sağlamada çeşitli yol ve yöntemler kullanılmıştır.

Amerikan İşçi Sendikaları Federasyonu (A.F.L.), Türkiye'de 1946 ve sonrasında kurulan sendikaları bir konfederasyon bünyesinde bir araya getirme, bir merkezden denetim ve güdümleri altına alma doğrultusunda ilk girişimlerini 1951 yılı Ocak ayında başlatmıştır. A.F.L.'den Boris Shiskin Türkiye'ye gelerek kurulacak bir konfederasyona Marshall yardımı çerçevesinde kaynak aktarabileceğini bildirmiştir (Koç, 1987:36-92'den aktaran Öz,1993:46).

Türk-İss resmen 31 Temmuz 1952'de 10 sendikalar birliği ve sendikalar federasyonu tarafından kurulmuştur (Sülker, 1987:182).

Türk-İş ile DP iktidarı arasındaki uyum, bu iki gücün rızası hilafına da olsa bozulmak zorunda kalmıştır. Bu alanda ilk büyük anlaşmazlık, 1954 yılında toplanan Çalışma Meclisi'nde ortaya çıkmıştır. Bu mecliste işçi önderlerinin çok istemiş olmasına ve Hükümet programında bulunmasına rağmen, DP'den çalışma yaşamının iyileştirilmesine ilişkin olumlu sözler alamamışlardır. Buna rağmen, Türk-İş̧'in hükümete karşı bir işçi muhalefeti örgütleyebildiği söylenemez (Işık, 1995:190).

1954 yılında Türk-İ̧s’e bağlı sendikaların sayısı 18, üye işçilerin sayısı ise 150 000'i bulmuştur. (Şişmanov, 1978:170).

1954 yılında başlayan AID (Uluslar arası Kalkınma Örgütü) yardımları 1962 yılına kadar Çalışma Bakanlığı tarafından Türk-İş’e iletilmekteydi. Ancak, 1962 yılından sonra bu yardımlar doğrudan Türk-İş’e verilmeye başlanmıştır (Tüm İktisatçılar Birliği, 1976:106).

Bunun iki nedeni vardır. Birincisi, Türk-İş, kurulduğundan bugüne dek siyasal iktidarları doğrudan karşısına alan bir politika izlememiştir. Bu anlayış, 1960'l1 y1llardan sonra kendisini daha net bir biçime getirmiş ve ünlü "partiler üstü politika" haline dönüşmüştür. İkinci neden ise daha pratik bir dayanağa sahiptir. 1947 sendikacılığı, sendikaları hükümete mali olarak bağımlı hale getirmiştir. Sendikaların aidatlarını "kaynakta kesinti" sistemiyle değil de, gönüllüliük esasına göre toplamış olmaları, örgütlenme geleneğine sahip olmayan sendikaları, mali güçlükle karşı karşıya bırakmış; bu güçlüğü 
aşabilmek için hükümet yardımı devreye girmiştir. Bu da, sendikal hareketin kıskaca alınabilmesi için önemli bir neden olmuştur (Işık, 1995:190).

Türk-İş'in Ocak 1964'te toplanan Genel Kurulunda, tüzüğüne de geçmiş bulunan "partiler üstui politika" ilkesi, Amerikan sendikacılığına egemen olan "tarafsız" (non-partisan) politika ilkesinin bir benzeridir (Dereli, 1996:4144, Işıkl1,1990:354).

\section{Sonuç}

Sendikalar, işçilerin; işyeri ve toplumsal alanlarda çıkarlarını sağlamak, haklarını elde etmek ve özgürlüklerini genişletmek için kurdukları örgütler olarak tanımlanabilir.

Asıl amacı işçi hareketini örgütlemek, onların hak ve çıkarlarını korumak, kendileri için sistemin yarattığı sonuçları hafifletmek olan işçi sınıfı ve onların örgütleri olan sendikaların, ülkemizde siyasetçilerin ve diğer güç sahiplerinin arzu ve çıkarlarını yerine getirmek için kurulduğu; sendikaların siyasi yönetim tarafından devamlı olarak denetim altında tutulduğu, Batıdan farklı bir sınıfsal güç olarak ortaya çıkamadıkları ve toplumsal dinamikleri etkileme açısından ciddi manada etkili olamadıkları söylenebilir. Türk toplumunun sanayileşme sürecindeki geri kalmışlığı ve demokrasi geçmişinin çok yeni olduğu için bu durum Türkiye'de sendikaların doğuş süreci açısından doğal karşıllanmalıdır.

Görüldügü üzere Türkiye ve Batı ülkeleri açısından sendikacıllğın doğuşu ve gelişimi açısından önemli benzerlikler ve farklılıklar vardır. En önemli benzerlik hem Batıda hem de bizim ülkemizde sendikal hareketler kolay kolay kabul görmemiş ve siyasal iktidarlar tarafından ciddi yasaklamalarla karşılaşmışlardır. Özellikle bu yasaklamalar sendikaların doğuş yıllarında hem Batıda hem de bizim ülkemizde yaşanmıştır. Temel farklılık ise Batının önceden sanayileşmiş ve demokratik yaşama daha önceden geçmiş olduğu için sendikal faaliyetlerin Batıda sosyal bir sınıf temeli üzerinde cereyan etmesidir. Türkiye'de ise Batıdaki anlamında bir işçi sınıfının yokluğundan dolayı az sayıda ve toplumsal bir taban oluşturacak düzeyde olmayan işçilerin sendikal faaliyetleri siyasal iktidarlar tarafından daha kolay kontrol altında tutulabilmiştir. Türkiye'nin Cumhuriyetin kuruluşundan itibaren on y1llar boyunca devletçi bir ekonomi politikası uygulaması sonucu üretim birimlerinde çalışan kişileri işçi olarak görmek doğru değildir. İşçi, tanımı gereği, piyasa koşullarında emeğinin karşılığı geçimini sağlayan kişilerdir. Devlet işletmelerinde çalışan kişiler ise, devletin geçimlerini sağladığı kişilerdir. Devletçi bir ekonomik politikanın uygulandığı yerde işçi sınıfından ve onun toplumsal gücünden söz etmek ne kadar tutarlı olacaktır.

Öncelikle sendikaların asıl doğuş nedeni ele alınacak olursa sanayi devrimi sonrasında ortaya çıkan yaşam koşulları, işçilerin bu koşullardan olumsuz etkilenmeleri haklarını aramalarına ve mücadele etmelerine neden 
olmuştur. Türkiye'ye bakıldığında ise Sanayi Devrimi'nin yaşanmaması, tarıma dayalı bir toplum olması ve işçilerin bu süreçten Batı'daki gibi etkilenmemesi farklılığın asıl nedenidir. Türkiye'de ilk sendikaların ortaya çıkışına bakıldığında karşımıza Amerikan tipi sendikacılık çıkmakta, işçi hakları işveren yararına olan bir sendikacılıkla aranmaya çalışılmaktadır.

Türkiye'de sendikacılığa gelişim süreci açısından bakıldığında da benzer sorunlar karşımıza çıkmaktadır. Sendikaların asıl amacı işçi çıkarlarını korumaktan çıkıp, siyasi ve ideolojik fikirlerin iş hayatındaki yansıması olmuştur. Hatta bazı sendikalar partiler üstui politika izleyerek iktidarda hangi parti varsa o partinin istekleri doğrultusunda hareket etmiş, iktidar partisi ile ters düşmenin kayıp anlamına geldiği düşünülmüştür. Avrupa'da ise durum tamamen farklıdır, eğer işçi çıkarlarına aykırı bir durum varsa, sendikalar iktidar partisi ile ters düşme pahasına işçi haklarını savunmuşlar ve sonunda da istediklerini almışlardır. Batıdaki sendikal faaliyetler sanayi devrimiyle birlikte sosyolojik bir taban üzerinde sancılı ve uzun bir süreç sonucunda doğmuş ve bugünkü durumuna gelmiştir. Türkiye'de sanayileşme süreci daha sonra başlamış, Batıdaki manada sendikal hareketlerin dayandığı toplumsal taban oluşmamış ve sendikal faaliyetlerde daha sun'i ve siyasal iktidarın kontrolünde ortaya çıkmıştır.

\section{Kaynaklar}

Ahmad, F. (1995), Modern Türkiye'nin Oluşumu, çev. Yavuz Alogan, Sarmal Yayınevi, İstanbul.

Ahmad, F. (1998), Osmanlı'dan Cumhuriyet Türkiye'sine İşçiler Cumhuriyet Türkiye'sinde Sinıf Bilincinin Oluşması, 1923-1940, der. Donald Quataert ve Erik Jan Zürcher, çev. Cahide Ekiz, 2. Baskı, İletişim Yayıncılık, İstanbul

Çeçen, A.(1973), Türkiye'de Sendikacılık, Özgür İnsan Yayınları, Ankara

Demircioğlu, A. M. (1987), Dünya'da İşçi Sendikaları, Basisen Eğitim ve Kültür Yayınları, İstanbul

Dereli, T. (1996), Amerikan Tipi Sendikacılık, Türkiye Sendikacılık Ansiklopedisi, Cilt 1, Kültür Bakanlığı ve Tarih vakfı, İstanbul

Ekin, N. (1987), Endüstri İlişkileri, 4.Baskı İ.Ü.Işşletme İktisadi Enstitüsü Yayınları, İstanbul

Ekin, N. (1989), Endüstri İlişkileri, 5. baskı, İşletme Fakültesi Yayını, İstanbul

Erişçi, L.(1951), Türkiye İşçi Sınıfının Doğuşu-Özet Olarak, Kurtulmuş Basımevi, İstanbul

Eroğul, C.(Nisan 1994), "46 Ruhunun Mirası Artık Herkesindir”, İktisat Dergisi, Yıl: 30, Say1: 348, s.44-49

Eroğul, C. (1970), Demokrat Parti, 1.Baskı, Siyasal Bilgiler Fakültesi Yayınları, Ankara

Gülmez, M. (1983), Türkiye'de Çalışma İlişkileri (1936 öncesi), TOAIE Yayınları, Ankara

Gülmez, M. (1995), Meclislerde İşçi Sorunu ve Sendikal Haklar (1909-1961), Öteki Yayınevi, Ankara 
Özkiraz, A. \& Talu, N. / Sosyal Bilimler Araştırmaları Dergisi. 2, (2008): 108-126

Işı1k, Y. Osmanlı'dan Günümüze İşçi Hareketinin Evrimi (1876-1994), Öteki Yayınevi, Ankara

Işıılı , A. (1990), Sendikacılık ve Siyaset, 4. Baskı, İmge Kitabevi, Ankara

Lafrance, G. , Sülker, K. (1966), Dünya'da ve Bizde Sendikacılık, Varlık Yayınları, İstanbul

Öz, Y. (1993), Türkiye'de İşçi Sendikalarının Üst Örgütlenmesi, Yayımlanmamış Yüksek Lisans Tezi, Gazi Üniversitesi Sosyal Bilimler Enstitüsü, Ankara

Savran, S. (1992), Türkiye'de Sinıf Mücadeleleri Cilt 1: 1919- 1980, Toplum Politika: 1 , Kardelen Yayınları

Sülker, K.(1955), Türkiye'de Sendikacılık, Vakit Matbaası, İstanbul

Sülker, K. (1987), Türkiye'de Sendikacılık Tarihi 1 Bilim Kitabevi Yayınları, İstanbul

Şişmanov, D. (1978), Türkiye'de İşçi ve Sosyalist Hareketi, haz.A.R.Zarakolu, Belge Yayınları, İstanbul

Talas,C. , Dilik, S., ve Işıklı, A. (1963), Türkiye'de Sendikacılık Hareketi ve Toplu Sözleşme, Siyasal Bilgiler Fakültesi Yayınları ,Ankara

Talas, C. (1976), Sosyal Ekonomi, S Yayınları, Ankara

Timur, T. (1997), Türk Devrimi ve Sonrası, İmge Kitabevi , Ankara

Tokol, A. (1984), İngiltere' de Sendikacılık ve Toplu Pazarlık Sistemi, U.Ü.İ.İ.B.F., Dergisi, Cilt 5, Sayı 1

Tokol, A. (2002), Avrupa Birliği’ne Üye Ülkelerde Sendikal Hareket, Vipaş, Bursa

Tunaya, T. Z. (1975), Siyasi Müesseler ve Anayasa Hukuku, 3. Baskı, IÜHF Yayını, İstanbul

Tüm İktisatçılar Birliği (1976 ), Türkiye'de İşçi Sınıfı Mücadeleleri Tarihi, 1.Baskı ,Tüm İktisatçılar Birliği Yayınları, Ankara

Yavuz, E. (1998), Sanayideki İşüicünün Durumu, 1923-1940, Osmanlı'dan Cumhuriyet Türkiye'sinde İşçiler, der. Donald Quatoert ve Erik Jan Zurcher, çev. Cahide Ekiz, 2. baskı, İletişim Yayıncılık, İstanbul

Yücel, A. (1980), Emek Ekonomosi ve Endüstri İlişkileri, Kalite matbaası, Ankara

Yükselbaba, Ü. (2001), Türkiye' de 1960'lara Kadar Sanayileşme Sürecinde İş Hukukunun Ortaya Çıkışı, Yayımlanmamış Yüksek Lisans Tezi, İstanbul Üniversitesi Sosyal Bilimler Enstitüsü, İstanbul

Zurcher, E. J. (2000), Modernleşen Türkiye'nin Tarihi, 7. Baskı, İletişim Yayınları, İstanbul. 